\title{
ANALOGS OF DEAMINO CARBA OXYTOCIN WITH INHIBITORY PROPERTIES; SYNTHESIS AND BIOLOGICAL ACTIVITIES*
}

\author{
Zdenko ProcházKa ${ }^{a}$, Jiřina Slaninova $\AA^{a}$, Tomislav Barth ${ }^{a}$, \\ Alena Stierandova ${ }^{a}$, Jerzy TrojNAR $^{b}$, Per Melin ${ }^{b}$ and Michal LeBL ${ }^{a}$ \\ - Institute of Organic Chemistry and Biochemistry, \\ Czechoslovak Academy of Sciences, 16610 Prague 6, Czechoslovakia \\ ${ }^{b}$ Ferring AB, Malmö. Sweden
}

Received September 13, 1991

Accepted October 30, 1991

Solid phase methodology on polyamide-kieselguhr resin was used for the synthesis of six analogs of deamino carba-1 or carba-6 oxytocin with non-coded amino acids in position 2 , threonine in position 4 , ornithine in position 8 and without glycine in position 9 . The following analogs were prepared: des-Gly ${ }^{9}-\left[\mathrm{L}-\mathrm{Phe}(p-\mathrm{Et})^{2}, \mathrm{Thr}^{4}, \mathrm{Orn}^{8}\right]$ deamino-carba-1-oxytocin $(I)$, des-Gly ${ }^{9}$ -[D-Phe $(p-E t)^{2}, \operatorname{Thr}^{4}$, Orn $\left.^{8}\right]$ deamino-carba-1-oxytocin $(I I)$, des-Gly ${ }^{9}-\left[D-T y r(E t)^{2}, \mathrm{Thr}^{4}, \mathrm{Orn}^{8}\right]$ deamino-carba-1-oxytocin (III), des-Gly ${ }^{9}-\left[\mathrm{L}-\mathrm{Phe}(p-\mathrm{Et})^{2}, \mathrm{Thr}^{4}, \mathrm{Orn}^{8}\right]$ deamino-carba-6-oxytocin (IV), des-Gly ${ }^{9}-\left[\mathrm{D}-\mathrm{Phe}(p-\mathrm{Et})^{2}, \mathrm{Thr}^{4}, \mathrm{Orn}^{8}\right]$ deamino-carba-6-oxytocin $(V)$, and des-Gly ${ }^{9}-[\mathrm{D}-$ $-\operatorname{Tyr}(\mathrm{Et})^{2}, \mathrm{Thr}^{4}, \mathrm{Orn}^{8}$ ]deamino-carba-6-oxytocin (VI). All the analogs were found to be strong uterotonic and pressor inhibitors. The highest potency in the uterotonic inhibitory test was exhibited by analog $I I\left(\mathrm{p} A_{2}=8 \cdot 3\right)$ and the strongest pressor inhibitor was compound $I$ ( $\mathrm{p} A_{2}=$ $=7 \cdot 5$ ).

Highly potent and selectively acting uterotonic inhibitor might find its application in human medicine especially if it would have a prolonged time course of action. Structure-activity studies in the field of neurohypophyseal hormone analogs** (for recent reviews see refs ${ }^{1,2}$ ) have led to discovery of several structural features yielding analogs with inhibitory properties. It is well documented that shortening of the peptide chain at the carboxy terminal part of the molecule destroys agonistic activities, but does not influence the inhibitory potency of the analog ${ }^{3.4}$. Ornithine in position 8 represents a very important modification for the uterotonic inhibitory activity ${ }^{5,6}$. On the other hand, the effects of threonine in position 4 , deamination in position 1 and carba substitution of the disulfide bridge on the inhibitory activity

\footnotetext{
- Part CCXXIX in the series Amino Acids and Peptides; Part CCXXVIII: Collect. Czech. Chem. Commun. 57, 1103 (1992).

** All the chiral amino acids, mentioned in this work, are of the L-series, if not specified otherwise. The nomenclature and symbols of the amino acids and peptides obey the published recommendations (Eur. J. Biochem. 138, 9 (1984)). Phe $(o$-Et) denotes $p$-ethylphenylalanine and Tyr(Et) the O-ethyltyrosine moiety.
}

Collect. Czech. Chem. Commun. (Vol, 57) (1992) 
are not clearly defined. All these modifications increase the agonistic activities and therefore, they are supposed to enhance also the affinity to the appropriate receptor. However, for example the combination of deaminopenicillamine in position 1 (normally leading to inhibitor) with carba substitution resulted in a quite potent uterotonic agonist which was transformed to a potent antagonist only by another modification of the tyrosine side chain ${ }^{7}$. Substitution of tyrosine hydroxy group, either by alkoxy or alkyl group, usually gives inhibitors or at least partial agonists (see e.g. refs $^{8,9}$ ), as well as the introduction of amino acids of D-configuration into position $2\left(\right.$ ref. $\left.^{10}\right)$. For recent review of structure-activity studies in the field of neurohypophyseal hormone inhibitors see ref. ${ }^{11}$. We decided to combine the structural features stated above to study their cooperativity for production of a potent uterotonic inhibitor.

All the synthesized analogs are of the deamino series (aminogroup on amino acid moiety in position 1 is replaced with hydrogen atom), without glycine in position 9 (des-glycine ${ }^{9}$-analogs); glutamine in position 4 is replaced by threonine and leucine in position 8 by ornithine. The disulfide bridge is modified by the so called carba substitution. In the first three analogs, the sulfur atom in position one is replaced with a methylene group (carba-1 analogs), in the last three analogs position six is modified (carba- 6 analogs). In position 2 , there are non-coded amino acids L- and $D$ - $p$-ethylphenylalanine and D-O-ethyltyrosine. The following analogs were prepared: des-Gly ${ }^{9}-\left[\mathrm{L}-\mathrm{Phe}(p-\mathrm{Et})^{2}, \mathrm{Thr}^{4}, \mathrm{Orn}^{8}\right]$ deamino-carba-1-oxytocin $(I)$, des-Gly ${ }^{9}-[\mathrm{D}-\mathrm{Phe}-$ $\left.(p-\mathrm{Et})^{2}, \mathrm{Thr}^{4}, \mathrm{Orn}^{8}\right]$ deamino-carba-1-oxytocin $(I I), \quad$ des-Gly ${ }^{9}-\left[\mathrm{D}-\mathrm{Tyr}(\mathrm{Et})^{2}, \mathrm{Thr}^{4}\right.$, $\mathrm{Orn}^{8}$ ]deamino-carba-1-oxytocin $(I I I)$, des-Gly ${ }^{9}-\left[\mathrm{L}-\mathrm{Phe}(p-\mathrm{Et})^{2}, \mathrm{Thr}^{4}, \mathrm{Orn}^{8}\right]$ deamino-carba-6-oxytocin $(I V)$, des-Gly ${ }^{9}-\left[\mathrm{D}-\mathrm{Phe}(p-\mathrm{Et})^{2}, \mathrm{Thr}^{4}, \mathrm{Orn}^{8}\right]$ deamino-carba-6-oxyto$\operatorname{cin}(V)$, and des-Gly 9 -[D-Tyr $\left.(\mathrm{Et})^{2}, \mathrm{Thr}^{4}, \mathrm{Orn}^{8}\right]$ deamino-carba-6-oxytocin $(V I)$.

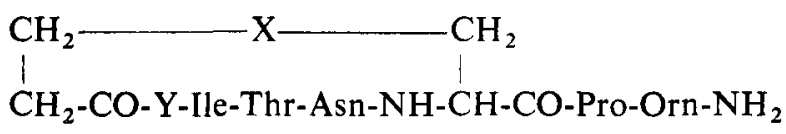

$$
\begin{aligned}
& I, \quad \mathrm{X}=\mathrm{CH}_{2}-\mathrm{S} ; \quad \mathrm{Y}=\mathrm{L}-\mathrm{Phe}(p-\mathrm{Et}) \\
& \text { II, } \mathrm{X}=\mathrm{CH}_{2}-\mathrm{S} ; \quad \mathrm{Y}=\mathrm{D}-\mathrm{Phe}(p-\mathrm{Et}) \\
& \text { III, } \mathrm{X}=\mathrm{CH}_{2}-\mathrm{S} ; \quad \mathrm{Y}=\mathrm{D}-\mathrm{Tyr}(\mathrm{Et}) \\
& I V, \mathrm{X}=\mathrm{S}-\mathrm{CH}_{2} ; \quad \mathrm{Y}=\mathrm{L}-\mathrm{Phe}(p-\mathrm{Et}) \\
& V, \quad \mathrm{X}=\mathrm{S}-\mathrm{CH}_{2} ; \quad \mathrm{Y}=\mathrm{D}-\mathrm{Phe}(p-\mathrm{Et}) \\
& V I, \mathrm{X}=\mathrm{S}-\mathrm{CH}_{2} ; \quad \mathrm{Y}=\mathrm{D}-\mathrm{Tyr}(\mathrm{Et})
\end{aligned}
$$

Pentafluorophenyl ester of $\mathrm{N}^{\alpha}$-fluorenyloxycarbonyl-S-(3-tert-butoxycarbonylpropyl)cysteine and pentafluorophenyl ester of $\mathrm{N}^{\alpha}$-fluorenyloxycarbonyl-S-(2-tert-butoxycarbonylethyl)homocysteine served as key intermediary products for the synthesis of carba analogs. These intermediates were prepared from S-(3-tert-butoxycarbonylpropyl)cysteine and S-(2-tert-butoxycarbonylethyl)homocysteine ${ }^{12,13}$ 
via dicyclohexylammonium salts of the corresponding $\mathrm{N}^{\alpha}$-fluorenylmethyloxycarbonyl derivatives. S-(3-Tert-butoxycarbonylpropyl)cysteine was obtained by alkylation of cysteine by tert-butyl ester of $\gamma$-bromobutyric acid. S-(2-Tert-butoxycarbonylethyl)homocysteine was prepared by reduction of homocystine with sodium in liquid ammonia and subsequent alkylation of the homocysteine with tert-butyl acrylate.

Syntheses of all the six analogs were performed by solid phase technique on the polyamide-kieselguhr resin. As the $\alpha$-amino group protection we have used fluorenylmethyloxycarbonyl group, only for the aminoterminal amino acid tert-butoxycarbonyl group was used. For the side chain protection we have used benzyloxycarbonyl (Orn) or tert-butyl (Thr) group. Protected amino acids were coupled by the pentafiuorophenyl active ester method in dimethylformamide. Acid-labile side chain protecting groups $\left(\mathrm{Boc}\right.$ and $\mathrm{Bu}^{t}$ ) were cleaved with trifluoroacetic acid before the cleavage of the peptide from the resin by liquid ammonia in methanol. The cyclization was carried out in dimethylformamide by diphenylphosphorylazide with dipotassium hydrogen phosphate ${ }^{14}$ and stabile side chain protecting group ( $\mathrm{Z}$ on ornithine) was cleaved by liquid hydrogen fluoride with anisole. Cyclic analogs were isolated and purified by HPLC. In syntheses of the analogs with $p$-ethylphenylalanine we took advantage of fact that diastereoisomeric peptides can be easily separated by reversed phase chromatography ${ }^{10,15,16}$. Preparation of these analogs was carried out with the mixture of L- and D-amino acids and the corresponding diastereoisomeric analogs were separated by HPLC at the end of the synthesis. With the knowledge that with sufficient excess of $\mathrm{L}$ and $\mathrm{D}$ components only one diastereoisomeric derivative ${ }^{17}$ is predominantly formed, only 1.1 equivalents of tert-butoxycarbonyl-D,L-p-ethylphenylalanine were used in this case.

Biological activities of the analogs are given in Table I. Since activities of the

TABLE I

Inhibitory activities (rat) of oxytocin analogs ( $\mathrm{p} A_{2}$ values). Values in parentheses were determined independently in Malmö laboratory

\begin{tabular}{|c|c|c|c|c|c|}
\hline \multirow{2}{*}{$\begin{array}{l}\text { Com. } \\
\text { pound }\end{array}$} & \multicolumn{3}{|c|}{ Uterotonic } & \multirow{2}{*}{$\begin{array}{c}\text { Dura- } \\
\text { tion }^{a} \\
\min \end{array}$} & \multirow{2}{*}{ Pressor } \\
\hline & & n vitro & in vivo & & \\
\hline$I$ & $8 \cdot 05 \pm 0 \cdot 20$ & $0(8.20 \pm 0.07)$ & $7.42 \pm 0.19(6.84 \pm 0.24)$ & $51 \pm 8$ & $7 \cdot 55$ \\
\hline $1 I$ & $8 \cdot 32 \pm 0.13$ & $3(8.39 \pm 0.21)$ & $7.44 \pm 0.25(7.73 \pm 0.16)$ & $81 \pm 14$ & $6.83 \pm 0.18$ \\
\hline III & $8 \cdot 15 \pm 0 \cdot 10$ & $0(8 \cdot 15 \pm 0 \cdot 14)$ & $6.75 \pm 0.08(6.92 \pm 0.17)$ & $60 \pm 9$ & 6.56 \\
\hline$I V$ & $8.43 \pm 0.25$ & & $7.45 \pm 0.24(7.45 \pm 0.15)$ & $87 \pm 11$ & $7.43 \pm 0.21$ \\
\hline$V$ & $8 \cdot 50 \pm 0 \cdot 18$ & $8(8.35 \pm 0.05)$ & $7.40 \pm 0.13(7.51 \pm 0.07)$ & $140 \pm 19$ & $6.42 \pm 0.09$ \\
\hline$V I$ & $8.75 \pm 0.20$ & $0(8.48 \pm 0.07)$ & $7.70 \pm 0.25(7.70 \pm 0.21)$ & $99 \pm 19$ & $6.9(6.12 \pm 0.04)$ \\
\hline
\end{tabular}

a Time after which the response to standard dose of oxytocin returned to $75 \%$ of its starting value; see ref. 9 . 
described compounds were found to be quite promising, their potencies were evaluated both in Prague and Malmö laboratories. This independent evaluation has shown, that the inhibitory activities determined at different places can be well correlated (see Table I) and that highly potent uterotonic inhibitors resulted from the substitutions performed on the oxytocin molecule. The highest $\mathrm{p} A_{2}$ value (8.75) was achieved with analog $V I$, containing O-ethyltyrosine of $\mathrm{D}$-configuration in position 2 . This modification is slightly more efficient in producing an inhibitor than $D$ - $p$ -ethylphenylalanine $\left(\mathrm{p} A_{2}=8.5\right)$ which was found by several authors ${ }^{9}$ to be the optimum substitution for achieving inhibitory properties of the analog. Comparison of carba- 1 and carba-6 substitutions of the disulfide bridge ( $I$ and $I V, I I$ and $V, I I I$ and VI), favours the carba- 6 modification. Evaluation of the in vivo inhibitory potency of these compounds showed that there are no substantial differences in the character of the response between the analogs containing L- or D-p-ethylphenylalanine in position 2 . However, carba- 6 analogs exhibit substantially more prolonged inhibitory action than carba-1 analogs. This may be explained by smaller influence of oxidation (which may play a role as one of the degradation processes) on the activity of carba-6 analogs in comparison to carba-1 ones, as was described in several cases ${ }^{18}$. The action of analogs containing D-Phe $(\mathrm{Et})$ is by about $40 \%$ more prolonged than of the corresponding analogs with D-Tyr(Et) in position 2 . This may be caused by cleavage of the $p$-substituent in the tyrosine derivative. Analog $V$ is by far the most prolonged uterotonic inhibitor we have ever tested.

The most potent pressor inhibitor was the analog $I V$ containing $p$-ethylphenylalanine of L-configuration $\left(\mathrm{p} A_{2}=7 \cdot 6\right)$ in position 2. The position of the sulfur replacement by $\mathrm{CH}_{2}$ apparently has not a dramatic influence on the pressor inhibitory activity.

We may conclude that the compounds synthesized as described in this paper, belong to the family of uterotonic antagonists with prolonged action. They may have a potential clinical value in preventing oxytocin receptor-dependent uterine hyperactivity in premature labour.

\section{EXPERIMENTAL}

Thin-layer chromatography (TLC) was carried out on silica gel coated plates (Silufol, Kavalier, Czechoslovakia) in the following systems: 2-butanol-98\% formic acid-water $(10: 3: 8)$ (S1), 2-butanol-25\% ammonia-water $(85: 7 \cdot 5: 7 \cdot 5)$ (S2), 1-butanol-acetic acid-water $(4: 1: 1)$ (S3), 1-butanol-acetic acid-pyridine-water $(15: 3: 10: 6$ ) (S4). Spots in TLC were detected by the chlorination method. Samples for amino acid analysis were analyzed on an Amino acid analyser LKB 4150. Optical rotations were determined on a Perkin-Elmer instrument type $141 \mathrm{MCA}$ (Norwalk, U.S.A.) at $20^{\circ} \mathrm{C}$. Fast atom bombardment mass spectra were obtained on a ZAB-EQ spectrometer (VG Analytical Ltd., Manchester) with xenon at $8 \mathrm{kV}$ as the bombarding gas. Analytical HPLC was carried out on an SP- 8800 instrument equipped with a Spectroflow 757 detector (Applied Biosystems) and SP-4290 integrator (SP from Spectra Physics, Santa Clara, 
U.S.A.) and on a Waters $\mu$ BONDAPAK C18 column. Preparative liquid chromatography was carried out on SepTech ST/Lab $800 \mathrm{C}$ instrument with Macrobore Annular Expansion column A $/$ E $(25 \times 7.5 \mathrm{~cm})$ filled with Kromosil C18 $(10 \mu \mathrm{m})$.

\section{$N^{\alpha}$-Fluorenylmethyloxycarbonyl- $N^{\delta}$-benzyloxycarbonylornithine Dicyclohexylammonium Salt}

$\mathrm{N}^{\delta}$-Benzyloxycarbonylornithine ${ }^{19}(7 \cdot 3 \mathrm{~g} ; 20 \mathrm{mmol})$ was suspended in the mixture of water $(50 \mathrm{ml})$ and acetonitrile $(100 \mathrm{ml})$ and disopropylethylamine $(6.8 \mathrm{ml})$ and Fmoc-ONSu $(7.4 \mathrm{~g}$; $22 \mathrm{mmol}$ ) were added, After stirring for $2 \mathrm{~h}$ at room temperature acetonitrile was evaporated, the residue was acidified with $1 \mathrm{M} \mathrm{HCl}$ and the product was extracted into ethyl acetate. Extract was washed with water, dried with sodium sulfate, filtered and evaporated. The residue was dissolved in ethyl acetate and after addition of dicyclohexylamine $(4 \mathrm{ml})$ the mixture was diluted with hexane. After several hours in the refrigerator, the crystals were filtered and washed with hexane. Yield $11.5 \mathrm{~g}(82 \%)$; m.p. $220-221^{\circ} \mathrm{C}$; $[\alpha]_{D}+7.5^{\circ}$ (c 0.52, ethanol). For $\mathrm{C}_{40} \mathrm{H}_{51} \mathrm{~N}_{3} \mathrm{O}_{6}$ (669.9) calculated: $71.72 \% \mathrm{C}, 7.67 \% \mathrm{H}, 6.27 \% \mathrm{~N}$; found: $71.95 \% \mathrm{C}, 7 \cdot 57 \% \mathrm{H}, 6.31 \% \mathrm{~N}$.

\section{S-(3-Tert-butoxycarbonylpropyl)cysteine}

Cystine $(10 \mathrm{~g})$ was dissolved in liquid ammonia $(500 \mathrm{ml})$ and sodium was added until blue color persisted for $5 \mathrm{~min}$. The solution was decolorized by addition of ammonium chloride, and tert-butyl ester of $\gamma$-bromobutyric acid $(28 \mathrm{~g})$ was added under stirring. Solution was evaporated in vacuo of water aspirator, the lyophilizate was dissolved in water $(250 \mathrm{ml})$ and extracted with ethyl acetate. The aqueous layer was cooled to $0^{\circ} \mathrm{C}$ and applied to the column of Dowex 50 $\left(\mathrm{H}^{+}\right.$form, $\left.300 \mathrm{ml}\right)$. The ion exchanger was washed with water to neutral reaction of the eluate and the product was eluted with $5 \%$ aqueous ammonia. Evaporation afforded $18.6 \mathrm{~g}(86 \%)$ of the cysteine derivative. $E_{2.4}^{\mathrm{Gly}} 0.48(0.48), E_{5.7}^{\mathrm{His}} 0.00(-0.63)$ (values in parenthesis are for the diacid prepared by trifluoroacetic acid treatment); $[\alpha]_{D}-12 \cdot 8^{\circ}$ (c $1.0,1 \mathrm{M}$ acetic acid). For $\mathrm{C}_{11} \mathrm{H}_{21} \mathrm{NO}_{4} \mathrm{~S}(263.4)$ calculated: $50 \cdot 17 \% \mathrm{C}, 8.04 \% \mathrm{H}, 5 \cdot 32 \% \mathrm{~N}$; found: $49 \cdot 83 \% \mathrm{C}, 8 \cdot 25 \% \mathrm{H}$, $5.06 \% \mathrm{~N}$.

The mixture of the S-(3-tert-butoxycarbonylpropyl)cysteine $(1.4 \mathrm{~g}, 5 \mathrm{mmol})$, water $(7.5 \mathrm{ml})$ and acetonitrile $(7.5 \mathrm{ml})$ was stirred with disopropylethylamine $(0.85 \mathrm{ml})$ and Fmoc-ONSu $(1.87 \mathrm{~g}, 5.5 \mathrm{mmol})$ for $30 \mathrm{~min}$. The product was isolated similarly as above. Yield $2.93 \mathrm{~g}(86 \%)$; m.p. $142-143^{\circ} \mathrm{C} ;[\alpha]_{D}+2.8^{\circ}$ (c 0.36, ethanol). For $\mathrm{C}_{38} \mathrm{H}_{54} \mathrm{~N}_{2} \mathrm{O}_{6} \mathrm{~S}(666.9)$ calculated: $68.44 \% \mathrm{C}$, $8 \cdot 16 \% \mathrm{H}, 4 \cdot 20 \% \mathrm{~N}$; found: $68 \cdot 22 \% \mathrm{C}, 8 \cdot 02 \% \mathrm{H}, 4 \cdot 11 \% \mathrm{~N}$.

Pentafluorophenyl Ester of $\mathrm{N}^{\alpha}$-Fluorenylmethyloxycarbonyl-S-(3-tert-butoxycarbonylpropyl)cysteine

$\mathrm{N}^{\alpha}$-Fluorenylmethyloxycarbonyl-S-(3-tert-butoxycarbonylpropyl)cysteine dicyclohexylammonium salt $(2.05 \mathrm{~g}, 3 \mathrm{mmol})$ was suspended in ethyl acetate and shaken with $0.5 \mathrm{M} \mathrm{H}_{2} \mathrm{SO}_{4}$; the organic layer was washed with water, dried by sodium sulphate, filtered and evaporated. To the residue dissolved in ethyl acetate $(6 \mathrm{ml})$, pentafluorophenol $(0.61 \mathrm{~g})$ and dicyclohexylcarbodiimide $(0.68 \mathrm{~g})$ were added and after $1 \mathrm{~h}$ of stirring at room temperature and $2 \mathrm{~h}$ standing in the refrigerator, dicyclohexylurea was filtered off, the filtrate was concentrated and diluted with hexane. After several hours in refrigerator, crystalline portion was filtered and washed with hexane. Yield $1.7 \mathrm{~g}(86 \%) ;$ m.p. $61-62^{\circ} \mathrm{C} ;[\alpha]_{D}-23.5^{\circ}$ (c 0.2 , methanol). For $\mathrm{C}_{32} \mathrm{H}_{30} \mathrm{~F}_{5} \mathrm{NO}_{6} \mathrm{~S}(651 \cdot 7)$ calculated: $58.98 \% \mathrm{C}, 4.64 \% \mathrm{H}, 2 \cdot 15 \% \mathrm{~N}$; found: $58.92 \% \mathrm{C}, 4.68 \% \mathrm{H}, 2 \cdot 24 \% \mathrm{~N}$. 


\section{S-(2-Tert-butoxycarbonylethyl)homocysteine}

Homocystine ${ }^{20}(8.06 \mathrm{~g}, 30 \mathrm{mmol})$ was reduced by sodium in liquid ammonia $(300 \mathrm{ml})$. After the solution had been decolorized by ammonium chloride, the solution was lyophilized in the vacuo of a water aspirator. The lyophilizate was dissolved in water $(120 \mathrm{ml}$, pre-bubbled through with nitrogen) at $0^{\circ} \mathrm{C}$ and $\mathrm{pH}$ of the solution was adjusted to 8.1 by $1 \mathrm{M} \mathrm{HCl}$. Tert-butyl acrylate $(17.4 \mathrm{ml}, 120 \mathrm{mmol})$ was added to this solution during $15 \mathrm{~min}$ and the reaction mixture was stirred under nitrogen overnight. Separated product was filtered off, washed with ethanol and ether. Yield $6.75 \mathrm{~g}(41 \%)$ of electrophoretically pure product, which was found identical to the compound obtained in a different manner ${ }^{12}$. Aqueous filtrate was acidified by $1 \mathrm{M} \mathrm{HCl}$ to $\mathrm{pH} \mathrm{3}$, washed with ether and passed over a column of Dowex $50 \mathrm{Wx} 8\left(\mathrm{H}^{+}\right.$-form; $350 \mathrm{ml}$; precooled to $0^{\circ} \mathrm{C}$ ). The column was washed with water, the product was eluted with $10 \%$ solution of pyridine and evaporated to dryness. Yield $6.8 \mathrm{~g}(41 \%)$ of the second crop, containing traces of dicarboxylic acid.

\section{$\mathrm{N}^{\alpha}$-Fluorenylmethyloxycarbonyl-S-(2-tert-butoxycarbonylethyl)homocysteine}

Dicyclohexylammonium Salt

This product was obtained from S-(2-tert-butoxycarbonylethyl)homocysteine $(2 \cdot 8 \mathrm{~g}, 10 \mathrm{mmol})$ using the same procedure as described above. The crude product was isolated from ethyl acetate and ether $(5.72 \mathrm{~g}, 84 \%)$ and was recrystallized from $80 \%$ aqueous ethanol. Yield $3.55 \mathrm{~g}(52 \%)$; m.p. $198-201^{\circ} \mathrm{C} ;[\alpha]_{D}+13 \cdot 1^{\circ}\left(c 0 \cdot 53\right.$, ethanol). For $\mathrm{C}_{38} \mathrm{H}_{54} \mathrm{~N}_{2} \mathrm{O}_{6} \mathrm{~S}(666.9)$ calculated: $68 \cdot 44 \% \mathrm{C}$, $8.16 \% \mathrm{H}, 4 \cdot 20 \% \mathrm{~N}$; found: $68.37 \% \mathrm{C}, 8.01 \% \mathrm{H}, 4.36 \% \mathrm{~N}$. Amino acid derivative released from its dicyclohexylammonium salt was found identical to that described earlier ${ }^{13}$.

Pentafluorophenyl Ester of $\mathrm{N}^{\alpha}$-Fluorenylmethyloxycarbonyl-

-S-(2-tert-butoxycarbonylethyl)homocysteine

$\mathrm{N}^{\alpha}$-Fluorenylmethyloxycarbonyl-S-(3-tert-butoxycarbonylethyl)homocysteine dicyclohexylammonium salt $(3.4 \mathrm{~g}, 5 \mathrm{mmol})$ was transformed to the active ester as in the case of the cysteine derivative. Yield $2.32 \mathrm{~g}(70 \%)$; m.p. $58-59^{\circ} \mathrm{C}$; $[x]_{\mathrm{D}}-27.8^{\circ}\left(\mathrm{c} 0.50\right.$, methanol). For $\mathrm{C}_{32} \mathrm{H}_{30} \mathrm{~F}_{5} \mathrm{NO}_{6} \mathrm{~S}$ (651.8) calculated: $58.98 \% \mathrm{C}, 4 \cdot 64 \% \mathrm{H}, 2 \cdot 15 \% \mathrm{~N}$; found: $58 \cdot 97 \% \mathrm{C}, 4 \cdot 70 \% \mathrm{H}, 2 \cdot 36 \% \mathrm{~N}$.

Pentafluorophenyl Ester of $\mathrm{N}^{*}$-Tert-butoxycarbonyl-D,L-p-ethylphenylalanine

$\mathrm{N}^{\alpha}$-Tert-butoxycarbonyl-D,L-p-ethylphenylalanine $(0.88 \mathrm{~g}, 3 \mathrm{mmol})$ was dissolved in ethyl acetate $(6 \mathrm{ml})$ together with pentafluorophenol $(0.61 \mathrm{~g})$ and dicyclohexylcarbodiimide $(0.68 \mathrm{~g})$, and after $1 \mathrm{~h}$ of stirring at room temperature and $2 \mathrm{~h}$ standing in refrigerator, the urea was filtered off; the filtrate was concentrated in vacuo and diluted with hexane. Crystals were separated in the refrigerator and washed with hexane. Yield $087 \mathrm{~g}(63 \%)$ m.p. $95-96^{\circ} \mathrm{C}$. For $\mathrm{C}_{22} \mathrm{H}_{22} \mathrm{~F}_{5} \mathrm{NO}_{4}$ (459.4) calculated: $57.52 \% \mathrm{C}, 4.83 \% \mathrm{H}, 3.05 \% \mathrm{~N}$; found: $57.84 \% \mathrm{C}, 4.78 \% \mathrm{H}, 2.79 \% \mathrm{~N}$.

\section{Pentafluorophenyl Ester of $\mathrm{N}^{\alpha}$-Tert-butoxycarbonyl-O-ethyl-D-tyrosine}

The title compound was prepared from $\mathrm{N}^{x}$-tert-butoxycarbonyl-O-ethyl-D-tyrosine $(0.96 \mathrm{~g}$, $3 \mathrm{mmol}$ ) analogously as above. Yield $1.1 \mathrm{~g}(77 \%)$; m.p. $103-104^{\circ} \mathrm{C} ;[\alpha]_{D}+16.1^{\circ}(\mathrm{c} 0.51$, methanol). For $\mathrm{C}_{22} \mathrm{H}_{22} \mathrm{~F}_{5} \mathrm{NO}_{3}(475 \cdot 5)$ calculated: $55 \cdot 58 \% \mathrm{C}, 4.66 \% \mathrm{H}, 2.95 \% \mathrm{~N}$; found: $55 \cdot 39 \% \mathrm{C}$, $4.61 \% \mathrm{H}, 2 \cdot 87 \% \mathrm{~N}$.

\section{Solid Phase Peptide Synthesis}

A) Solid-phase peptide synthesis was carried out on MilliGen 9050 PepSynthesizer instrument 
with polyamide-kieselguhr resin (type PepSyn KB; $0.09 \mathrm{meq} / \mathrm{g}$ ). Synthesis was carried out with $2.2 \mathrm{~g}$ resin $(0.2 \mathrm{mmol})$ using the flow-through method on a column and with recycling in the case of coupling. The first amino acid was incorporated by means of the symmetric anhydride method. A cycle for incorporation of the amino acid residue into the growing peptide chain consisted of the following steps: 1 . cleaving the Fmoc group by washing with $20 \%$ piperidine in dimethylformamide for $10 \mathrm{~min}$; 2 . washing with dimethylformamide for $12 \mathrm{~min} ; 3$. coupling with 4 equivalents of active ester of the Fmoc-protected amino acid derivative in dimethylformamide for $45 \mathrm{~min}$; (in the case of D,L-p-ethylphenylalanine derivative, only $1 \cdot 1$ equivalents of active ester of the Boc-protected amino acid derivative in dimethylformamide for $4 \mathrm{~h}$ was used and additional coupling with 0.8 equivalents of the amino acid derivative and 0.8 equivalents of N,N-dimethylaminopyridine for another $1 \mathrm{~h}$ ); 4 . washing with dimethylformamide for $8 \mathrm{~min}$. The following protected derivatives were used: Fmoc-Orn $(\mathrm{Z})-\mathrm{OH} . \mathrm{DCHA}$, Fmoc-Pro-OPfp, Fmoc-Cys $\left(\mathrm{C}_{3} \mathrm{H}_{6} \mathrm{CO}_{2} \mathrm{Bu}^{t}\right)$-OPfp (for carba-1 analogs) or Fmoc- $\mathrm{Hcy}\left(\mathrm{C}_{2} \mathrm{H}_{4} \mathrm{CO}_{2} \mathrm{Bu}^{\mathrm{t}}\right.$ )-OPfp (for carba-6 analogs), Fmoc-Asn-OPfp, Fmoc-Thr-ODhbt, Fmoc-Ile-OPfp and Boc-D,L-Phe( $p$-Et)-OPfp or Boc-D-Tyr(Et)-OPfp. After taking out the resin from the column, Boc and Bu protecting groups were cleaved with the mixture of trifluoroacetic acid, dichloromethane and anisole (45:45:10; twice $15 \mathrm{~min}$ ). The resin was washed with dichloromethane, methanol, dichloromethane. $5 \%$ diisopropylethylamine in dichloromethane and dichloromethane.

$B$ ) Alternative synthesis of analog $V I$ was performed on semiautomatic peptide synthesizer using aminomethyl resin ( $1 \mathrm{~g}, 1 \mathrm{mmol} \mathrm{NH} / \mathrm{g}$, Peptide Intermediates, Prague), substituted by


A cycle for incorporation of one amino acid residue into the growing peptide chain consisted of the following steps: 1 . cleavage of Fmoc group by $20 \%$ piperidine in dimethylformamide for $20 \mathrm{~min} ; 2$. washing with dimethylformamide $(5 \times 2 \mathrm{~min}) ; 3$. coupling with 3 equivalents of Fmoc amino acid, HOBt and disopropylcarbodiimide (monitoring by bromophenol blue method ${ }^{22}$ ); 4. washing with dimethylformamide $(5 \times 2 \mathrm{~min})$. The following protected derivatives were used: Fmoc-Orn(Z)-OH, Fmoc-Pro-OH, Fmoc- $\mathrm{Hcy}\left(\mathrm{C}_{2} \mathrm{H}_{4} \mathrm{CO}_{2} \mathrm{Bu}^{\mathrm{t}}\right)-\mathrm{OH}$, Fmoc-Asn(Trt)-OH, Fmoc$-\mathrm{Thr}\left(\mathrm{Bu}^{\mathrm{t}}\right)-\mathrm{OH}, \mathrm{Fmoc}-\mathrm{Ile}-\mathrm{OH}$ and Boc-D-Tyr(Et)-OH. After taking out the resin from the reactor and proper washing, peptide was deprotected and cleaved from the resin by the mixture of trifluoroacetic acid $(95 \%)$, anisole $(2 \%)$, ethanedithiol $(2 \%)$, and water $(1 \%)$ (twice $30 \mathrm{~min})$. The product after evaporation was dissolved in $3 \mathrm{M}$ acetic acid and lyophilized. The first treatement afforded $0.5 \mathrm{~g}$ of product slightly contaminated with the peptide with deprotected ornithine side chain. The second TFA treatment gave another $0.27 \mathrm{~g}$ of the product containing substantial amount of side chain deprotected peptide.

Ammonolytic Cleavage of the Peptide from the Resin (A)

The peptide on the resin was left aside overnight at room temperature in a mixture of methanol $(50 \mathrm{ml})$ and liquid ammonia $(100 \mathrm{ml})$. The resin was filtered off, washed with methanol and the solution was evaporated to dryness. The residue was precipitated from a small amount of methanolic ammonia and ether, filtered and washed with ether. Yields, electrophoretic mobilities and HPLC constants are given in Table II.

The Cyclization (B)

To the solution of the heptapeptide $(80-130 \mathrm{mg})$ in dimethylformamide $(20-25 \mathrm{ml})$, cooled to $0^{\circ} \mathrm{C}, \mathrm{K}_{2} \mathrm{HPO}_{4}(90-140 \mathrm{mg})$ and diphenylphosphoryl azide $(40-70 \mu \mathrm{l})$ were added. Cyclization was followed by HPLC. If most of the starting compound was not consumed by cyclization in $8 \mathrm{~h}$, another DPPA $(100 \mu \mathrm{l})$ was added. After $24 \mathrm{~h}$, the starting compound was never detected. 


\section{TABLE II}

The values for analogs after ammonolysis (A) and cyclization (B)

\begin{tabular}{|c|c|c|c|c|c|c|}
\hline \multirow{3}{*}{ Compound } & \multicolumn{5}{|c|}{ A } & \multirow{3}{*}{$\begin{array}{c}\text { B } \\
\text { Yield }\end{array}$} \\
\hline & \multirow{2}{*}{ Yield } & \multicolumn{2}{|c|}{$k$} & \multirow{2}{*}{$E_{2.4}^{G l y}$} & \multirow{2}{*}{$E_{5.7}^{\mathrm{His}}$} & \\
\hline & & $60 \% \mathrm{MeOH}$ & $50 \% \mathrm{MeOH}$ & & & \\
\hline$I$ & $102 \mathrm{mg}(48 \%)^{b}$ & $1 \cdot 20$ & 6.07 & 0.61 & 0.11 & $a$ \\
\hline II & $102 \mathrm{mg}(48 \%)^{b}$ & 3.03 & $20 \cdot 42$ & 0.61 & 0.11 & $a$ \\
\hline III & $80 \mathrm{mg}(38 \%)$ & $\operatorname{grad}$ & ent & - & - & $60 \mathrm{mg}$ \\
\hline IV & $132 \mathrm{mg}(62 \%)^{b}$ & grad & ient & - & - & $120 \mathrm{mg}^{b}$ \\
\hline$y$ & $132 \mathrm{mg}(62 \%)^{b}$ & grad & ient & - & - & $120 \mathrm{mg}^{b}$ \\
\hline$V I$ & $130 \mathrm{mg}(61 \%)$ & grad & ent & - & - & $74 \mathrm{mg}$ \\
\hline
\end{tabular}

${ }^{a}$ Values not determined (product was not desalted). ${ }^{b}$ Mixture of diastereoisomers.

TABLE III

The analytical values for analogs after HPLC purification

\begin{tabular}{|c|c|c|c|c|c|c|}
\hline Compound & $I$ & $I I$ & $I I I$ & $I V$ & $V$ & $V I$ \\
\hline Gradient $^{a}$, min & 60 & 60 & 90 & 120 & 120 & 120 \\
\hline Yield, mg & 8.9 & $10 \cdot 4$ & $13 \cdot 0$ & $15 \cdot 4$ & $14 \cdot 6$ & $38 \cdot 7$ \\
\hline Yield, \% & 10 & 12 & 7 & 17 & 16 & 21 \\
\hline$k\left(25 \% \mathrm{CH}_{3} \mathrm{CN}\right)$ & $8 \cdot 1$ & $14 \cdot 5$ & $8 \cdot 1$ & $8 \cdot 7^{b}$ & $12 \cdot 3^{b}$ & $5 \cdot 0$ \\
\hline FAB MS & 904 & 904 & 919 & $903 \cdot 5$ & 903.5 & 919 \\
\hline \multicolumn{7}{|c|}{ Amino acid analysis } \\
\hline Asp & $1 \cdot 1$ & $1 \cdot 0$ & $1 \cdot 1$ & $1 \cdot 0$ & $1 \cdot 1$ & $1 \cdot 1$ \\
\hline Thr & $1 \cdot 0$ & $1 \cdot 0$ & $1 \cdot 0$ & $1 \cdot 1$ & $1 \cdot 0$ & $1 \cdot 1$ \\
\hline Asp & $1 \cdot 1$ & $1 \cdot 0$ & $1 \cdot 1$ & $1 \cdot 0$ & $1 \cdot 1$ & $1 \cdot 1$ \\
\hline Thr & $1 \cdot 0$ & $1 \cdot 0$ & $1 \cdot 0$ & $1 \cdot 1$ & $1 \cdot 0$ & $1 \cdot 1$ \\
\hline Pro & 0.9 & 0.9 & $1 \cdot 0$ & 0.9 & 0.9 & $1 \cdot 0$ \\
\hline $\mathrm{Cys}\left(\mathrm{C}_{3} \mathrm{H}_{6} \mathrm{COOH}\right)$ & 0.8 & 0.9 & $0 \cdot 9$ & - & - & - \\
\hline $\mathrm{Hcy}\left(\mathrm{C}_{2} \mathrm{H}_{4} \mathrm{COOH}\right)$ & - & - & - & 0.8 & 0.8 & 0.7 \\
\hline Ile & $1 \cdot 0$ & 1.0 & 0.9 & $1 \cdot 0$ & 1.0 & $1 \cdot 0$ \\
\hline Tyr & - & - & 0.6 & - & - & $1 \cdot 0$ \\
\hline $\operatorname{Phe}(p-E \mathfrak{t})$ & 0.9 & 0.9 & - & 0.9 & 0.9 & - \\
\hline Orn & $1 \cdot 0$ & $1 \cdot 1$ & $1 \cdot 0$ & $1 \cdot 1$ & $1 \cdot 1$ & $1 \cdot 2$ \\
\hline
\end{tabular}

${ }^{a}$ See Experimental. ${ }^{b}$ Vydac 218TP54 column.

Collect. Czech. Chem. Commun. (Vol. 57) (1992) 
The reaction mixture was filtered, evaporated, the residue was treated with water, left in a refrigerator, and the aqueous layer was separated from the oily residue by decantation. The oil was dissolved in methanol, dried by evaporation with benzene, and treated with ether. The precipitate was filtered and washed with ether. Yields are given in Table II. In another approach the residue after evaporation of dimethylformamide was dissolved in $3 \mathrm{M}$ acetic acid and gel-filtered on Sephadex G-15.

Cleavage of the Benzyloxycarbonyl Group from Ornithine

The cyclic peptide was treated with liquid hydrogen fluoride $\left(5 \mathrm{ml}, 10 \mathrm{~min}, 20^{\circ} \mathrm{C}\right)$ in the presence of anisole $(0.5 \mathrm{ml})$. The deprotected peptide was disolved in mixture of ethyl acetate and water after evaporation of hydrogen fluoride, the free peptide was extracted into water and lyophilized. In the preparation of $V I$ in larger scale, the protected peptide was treated with HF for $30 \mathrm{~min}$ at $0^{\circ} \mathrm{C}$ and after evaporation of HF purified by gel filtration (Sephadex G-15, 3M acetic acid). The yield was $51 \cdot 2 \mathrm{mg}(71 \%)$.

\section{The HPLC Purification}

The free cyclic peptide was disolved in $5 \mathrm{ml} 1 \mathrm{M}$ acetic acid and introduced onto the column containing Kromosil $\mathrm{C} 18$. The product was eluted by gradient running from $0 \%$ to $30 \%$ of acetonitrile in $60-120 \mathrm{~min}$ (see Table III), continuing isocratically at $30 \%$ of acetonitrile at the flow $60 \mathrm{ml} / \mathrm{min}$. In the case of diastereoisomeric analogs prepared with $\mathrm{D}, \mathrm{L}-\mathrm{Phe}(p-\mathrm{Et})$ two peaks were isolated. The appropriate fractions were collected and lyophilized. Yields, HPLC constants, amino acid analyses and FAB MS are given in Table III.

\section{Pharmacological Methods}

Uterotonic activity in vitro was determined on an isolated strip of rat uterus ${ }^{23,24}$. For determination of the uterotonic activity in vivo estrogenized rats under ethanol or Inactin anaesthesia were used ${ }^{25}$. Pressor activity was determined on pithed rats ${ }^{26}$. Inhibitory potencies were expressed by the $\mathrm{pA}_{2}$ values ${ }^{27,28}$. Prolongation of the uterotonic inhibitory activity was determined in rats in natural oestrus anaesthetized with Inactin ${ }^{9}$. The value of the inhibitor effect duration was determined as the time during which $75 \%$ of the original activity of the agonist (oxytocin) was retained after an inhibition of more than $60 \%$ of a standard dose of oxytocin.

The authors are indebted to I. Hoškova for skillful technical assistence in pharmacological evaluation, to Mr S. Nilsson and J. Zbrozek for the amino acid analyses and Dr K. Ubik for the FAB MS measurement. This work was supported in part by Czechoslovak Academy of Sciences Grant No. 45531.

\section{REFERENCES}

1. CRC Handbook of Neurohypophyseal Hormone Analogs (K. Jošt, M. Lebl and F. Brtník, Eds). CRC Press, Boca Raton 1987.

2. Hruby V. J., Smith C. W. in: The Peptides (S. Udenfriend and J. Meienhofer, Eds), Vol. 8, p. 77. Academic Press, New York 1987.

3. Lebl M., Barth T., Servitová L., Slaninová J., Jošt K. in: Peptides 1982. Proc. 17th Eur. Pept. Symp. (K. Bláha and P. Malon̆, Eds), p. 457. de Gruyter, Berlin 1983. 
4. Manning M., Olma A., Klis W., Kolodziejczyk A., Nawrocka E., Misicka A., Seto J., Sawyer W. H.: Nature 308, 5960 (1984).

5. Bankowski K., Manning M., Seto J., Haldar J., Sawyer W. H.: Int. J. Pept. Protein Res. 16, 382 (1980).

6. Sawyer W. H., Haldar J., Gazis D., Seto J., Bankowski K., Lowbridge J., Turan A., Manning M.: Endocrinology 106, 81 (1980).

7. Lebl M., Barth T., Servítová L., Slaninová J., Hrbas P.: Collect. Czech. Chem. Commun. 49, 2012 (1984).

8. Rudinger J. in: Drug Design (E. J. Ariens, Ed.), Vol. 2, p. 319. Academic Press, New York 1971.

9. Melin P., Vilhardt H., Lindenberg G., Larsson L.-E., Akerlund M.: J. Endocrinol. 88, 173 (1981).

10. Lebl M., Barth T., Servitová L., Slaninová J., Jošt K.: Collect. Czech. Chem. Commun. 50, 132 (1985).

11. Lebl M. in: CRC Handbook of Neurohypophyseal Hormone Analogs (K. Jošt, M. Lebl and F. Brtnik, Eds), Vol. 2, part 1, p. 17. CRC Press, Boca Raton 1987.

12. Lebl M., Cody W. L., Wilkes B. C., Hruby V. J., de L. Castrucci A. M., Hadley M. E.: Collect. Czech. Chem. Commun. 49, 2680 (1984).

13. Lebl M., Hruby V. J., Slaninová J., Barth T.: Collect. Czech. Chem. Commun. 50, 418 (1985).

14. Brady S. F., Varga S. L., Freidinger R. M., Schwenk D. A., Mendlowski M., Holly F. W., Veber D.: J. Org. Chem. 44, 3101 (1979).

15. Larsen B., Fox B. L., Burke M. F., Hruby V. J.: Int. J. Pept. Protein Res. 13, 12 (1979).

16. Lebl M.: J. Chromatogr. 264, 459 (1983).

17. Žertová M., Procházka Z., Bláha I., Barth T., Slaninová J., Lebl M.: Collect. Czech. Chem. Commun. 55, 3000 (1990).

18. Jošt K. in: CRC Handbook of Neurohypophyseal Hormone Analogs (K. Jošt, M. Lebl and F. Brtnik, Eds), Vol. 1, part 2, p. 144. CRC Press, Boca Raton 1987.

19. Barras B. C., Elmore D. T.: J. Chem. Soc. 1957, 3134.

20. Hope D. B., Humphries J. F.: J. Chem. Soc. 1964, 869.

21. Bernatowicz M. S., Daniels S. B., Koster H.: Tetrahedron Lett. 30, 4645 (1989).

22. Krchňák V., Vágner J., Safář P., Lebl M.: Collect. Czech. Chem. Commun. 53, 2542 (1988).

23. Holton P.: Br. J. Pharmacol. 3, 328 (1984).

24. Munsick R. A.: Endocrinology 66, 451 (1960).

25. Pliška V.: Eur. J. Pharmacol. 5, 253 (1969).

26. Krejđ̌l I., Kupková B., Vávra I.: Br. J. Pharmacol. Chemother. 30, 497 (1967).

27. Schild H. O.: Br. J. Pharmacol. 2, 189 (1947).

28. Slaninová J. in: CRC Handbook of Neurohypophyseal Hormone Analogs (K. Jošt, M. Lebl and F. Brtnik, Eds), Vol. I, part 2, p. 83. CRC Press, Boca Raton 1987.

Translated by the author (M.L.). 